\title{
Venture Capital and the TFP growth of Chinese Manufacturing Firms
}

\author{
Xi Yang ${ }^{1, ~ a}$ and Susheng Wang ${ }^{1, b}$ \\ ${ }^{1}$ Harbin Institute of Technology Shenzhen Graduate School, Shenzhen, China \\ a727943515@qq.com, ${ }^{\mathrm{b}} 611197033 @ q q . c o m$
}

\begin{abstract}
Keywords: Venture Capital; TPF; productivity efficiency, technological performance Abstract. Based on the panel data of SME firms in the manufacturing industry, this paper explores whether the involvement of venture capital can have significant impact on the manufacturing firms' performance in the productivity efficiency. The lagged value of the shareholding of $\mathrm{VC}$ firms is proven to be negatively correlated with the TFP growth of manufacturing firms. The DID models regression results also imply that Venture backing is negatively correlated with the TFP growth of manufacturing firms. As is concluded that, in the manufacturing sector, the Venture Capital firms in China act more like speculative investors who just care more about how to exit the investments in a short time by rushing the IPO process of the investees, which consequently leads to the inhibitory impact on the technological performance and productivity efficiency of the manufacturing firms.
\end{abstract}

\section{Introduction}

Technology innovation is regarded as the foundation and driving force for the sustainable economic growth and industrial structure upgrading. But, the externality of technology innovation implies that those firms engaged with the technology research and development activities usually involve with big uncertainty and high risks. Some scholars argue that the VC investments can promote the technological advancement and innovation through the following three mechanisms. Firstly, VC can offer equity financing for those start-up firms and can alleviate the severe financing constraints in the process of technology research and development, new technology innovation and the transformation and commercialization of the technological achievements [1]. Secondly, VC firms not only provide with the financial support but also offer the close monitoring and value-adding assistance for the entrepreneurs, to reduce the information asymmetry and lower the agency costs and risks [2]. What's more, the VC backing can bring the reputation effect on the funded firms in the capital market, which will help the investees get easier to establish and expand the networking with the local government, potential investors, business partners, key customers and suppliers. On the other hand, other scholars arguing the negative impact of VC investments advocate the following aspects. First, under the condition of the extreme information asymmetry; the VC capitalists will face high searching costs and will not be able to estimate the inner value or potential growth abilities of the ventures accurately. They are inclined to transfer high transaction costs to the funded firms, and offer the bidding price according to the average level in the sector[3]. Such might just drive away the better quality firms from the market, but only left with the inferior quality firms seeking for VC financing. Second, the special agency relationship between VCs and entrepreneurs usually bring the problems of double moral hazard risks. It remains a pending question that if the VCs in the emerging market of China can exert the positive impact on the manufacturing firms' productivity efficiency. This article aims to use the data of listed firms in the manufacturing industry on the China's SME board and testify the correlation between VC financing and the productivity efficiency (indexed by TFP) of manufacturing entrepreneurial firms , after controlling for the sample selection bias problems.

\section{Research Design}

We use TFP as dependant variable to index the productivity efficiency of venture firms. The total factor productivity (TFP), implying the firm's technological performance, can be calculated by dividing output by the weighted average of labor and capital input. And the TFP growth represents the residual 
growth in a firm's output after accounting for the growth in output attributable to the observable inputs of labor, capital, implying the efficiency enhancement by the advancement in the technology innovation, managerial skills, or the scales economy. As the productivity efficiency is our main concern and TFP usually differs quite well from industry to industry. This paper only chooses in the manufacturing industries on the SME Board in China to be the research samples of treatment group, which are listed between 2004 to 2014. To build the control group, we employ the PSM methodolgy[4] at the matching cateria of firm age and size, and finally we 185 non-venture backed firm as the matched control group firms. We get the financial data of these listed firms from WIND, and the VC financing information from Zero2IPO.

\section{Models}

The TFP estimation model. TFP is a measure of firm's productivity efficiency. As shown in Eq. 1, this article uses the semi-parametric LP method [5] to estimate the TFP of the entrepreneurial firm. $Y$ represents the output, indexed by the revenue of the firm; $K$ and $L$ represent the inputs of the firm (indexed by the total asset of the firm), and the staff number at the end of the year respectively. All of these key variables are logarithmic. Table 1 sums up the detailed discriptions of key variables.

$$
\operatorname{Ln} Y_{i t}=\alpha_{0}+\alpha_{1} \ln K_{i t}+\alpha_{2} \ln L_{i t}+\Sigma \alpha_{i} \text { Yeardummy }+\Sigma \alpha_{j} \text { Inddummy }+\varepsilon .
$$

The DID model to estimate VC's treatment effect on the TFP growth.To control for endogenetiy problems between VC investments and entreprenurial firms, we employ the DID model to estimate the treatment effect of VC financing. As shown in Eq. 2, the explained variable is TFP. Our main focus is the coefficients of the interation term (the interation term between the dummy vcpe and entry). The dummy vcpe indicates whether the firm is venture backed. If the firm is financed by VC firms before listing, the dummy vcpe equals 1 , otherwise 0 . The dummy entry represents the time of the $\mathrm{VC}$ financing. If it is after the ex-post involvement of VCs in the venture firms, it equals 1; otherwise 0 . The other control variables are $z z l, l e v, \ln r d$, etc. If $v c p e^{*} e n t r y$ is correlated with the TFP growth of venture firms in the positive way, we can infer that the treatment of VC financing on the firms TFP growth is positive. Otherwise, the $\mathrm{VC}$ financing put negative impact on the productivity efficiency of funded firms.

$$
\begin{aligned}
& \text { TFP } P_{i t}=\alpha_{i}+\beta_{1} \text { lntotalassetend }+\beta_{2} z z l+\beta_{3} \text { lev }+\beta_{4} \text { lnrdinvest }+\delta_{1} \text { Vcpe }+\delta_{2} \text { Entry } \\
& +\delta_{3} V_{\text {cpe }} * \text { Entry }+\sum \text { Naturedummy }+\sum \text { Yeardummy }+\xi_{i t} .
\end{aligned}
$$

\begin{tabular}{|c|c|}
\hline Variables & Definition and measurement \\
\hline TFP & The total factor productivity (calculated by LP semi prameter methodology) \\
\hline Y & The sales of the firm at the end of the year \\
\hline K & The number of total asset at the end of the year \\
\hline $\mathrm{L}$ & The number of staff at the end of the year \\
\hline Vcpe & $\begin{array}{l}\text { dummy variable: if the firm is financed by } \mathrm{VC} \text { firms before listing, the dummy is equal to } \\
1 \text {; otherwise, the dummy is equal to } 0\end{array}$ \\
\hline Entry & $\begin{array}{l}\text { dummy variable: if it is after the ex-post involvement of VCs in the venture firms, the } \\
\text { dummy is equal to } 1 \text {; otherwise, the dummy is equal to } 0\end{array}$ \\
\hline lev & The debt to assets ratio, measured by total debt/total asset \\
\hline$\Sigma \mathrm{Ndmy}$ & $\begin{array}{l}3 \text { dummy variables to represent firms with different ownership backgrounds: the private } \\
\text { firms, state-owned firms, foreign firms, and other firms }\end{array}$ \\
\hline$\Sigma$ Ydmy & 14 dummies representing obervations in different years \\
\hline$\Sigma$ Pdmy & 7 dummies representing firms from different provinces \\
\hline lnasset & the logarithm of Initial total assets \\
\hline $\mathrm{zzl}$ & Total asset turnover ratio, measured by the operating income/ average net assets \\
\hline vcshare & $\begin{array}{l}\text { The propotions of VCs' shareholding in the investee firms at the innitial round of VC } \\
\text { finnancing }\end{array}$ \\
\hline $\operatorname{lnrd}$ & The logarithm of expenditure on the Research and Development activities \\
\hline
\end{tabular}

Table 1 Variable Definitions 


\section{Analysis and Results}

To check the relationship between VC financing and funded manufacturing firm' TFP growth, we first retain the 191 firms with venture backing and testify the correlation between the lagged values of vcshare (the shareholdings of VCs in the funded firms at the initial round of investments) and TFP. If the lagged value of vcshare is negatively correlated with TFP, then it is proven that VC investments have negative ex-post impact on the efficiency of funded firms. As shown in Fig. 1, the correlation between vcshare (one year lagged) and the TFP is negative, and the slope is -1.23; in Fig. 2, the correlation between vcshare (2 year lagged) and the TFP is negative, and the slope is -0.7; and in Fig. 3, the correlation between vcshare ( 3 year lagged) and the TFP is also negative, and the slope is -0.4. Altogether, the more shareholding of VC firms will bring the future more decreasing in the productivity efficiency of funded firms. And such negative impact will get weaker with the longer duration of VC investment..



Fig. 1 The VC's share ( 1 year lagged ) and the investee's TFP

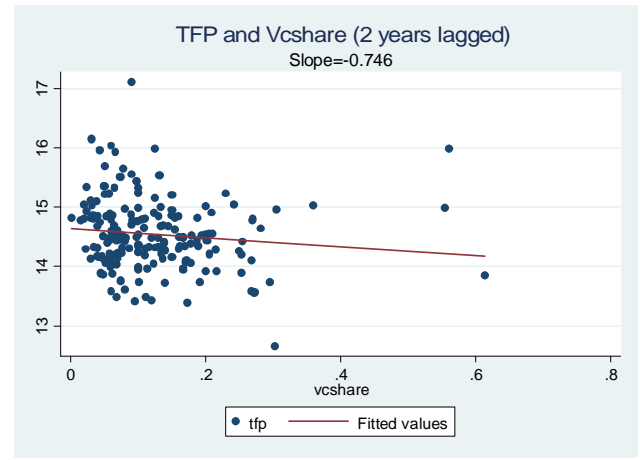

Fig. 2 The VC's share ( 2 year lagged ) and the investee's TFP

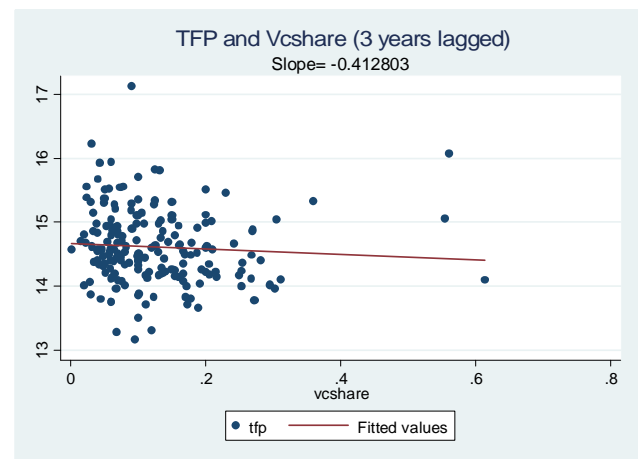

Fig. 3 The VC's share ( 3 year lagged ) and the investee's TFP

Then we used to total sample firms including $191 \mathrm{VC}$ backed firms and 185 non venture backed firms to run the DID models. From Table 2, we can see that the coeffecient of vcpe*entry is - 0.01 , siginificantly negative on the level of 0.05 . After the involvement of $\mathrm{VC}$ financing, the productivity efficiency of manufacturing firms would decrease 0.01 . The ex-post impact of $\mathrm{VC}$ financing is negative 
on the TFP growth of entreprenurial firms in the manufacturing industry.

Table 2 The VCs' treatment effect on the firms' productivity efficiency

\begin{tabular}{lll}
\hline Explained variable:TFP & Coefficient & T-value \\
\hline lnasset & $0.613^{* * *}$ & 75.43 \\
zzl & $0.933^{* * *}$ & 78.29 \\
lev & -0.0377 & -1.20 \\
vcpe & -0.0111 & -0.32 \\
Vcpe*Entry & $-0.0116^{* * *}$ & -2.32 \\
Entry & $-0.0655^{* * *}$ & -2.52 \\
Firm Fixed Effect & $\mathrm{Y}$ & $\mathrm{Y}$ \\
¿Pdmy & $\mathrm{Y}$ & $\mathrm{Y}$ \\
$\Sigma$ Ndmy & $\mathrm{Y}$ & $\mathrm{Y}$ \\
$\Sigma$ Ydmy & $\mathrm{Y}$ & $\mathrm{Y}$ \\
lnrd & $0.0354^{* * *}$ & 6.12 \\
cons & $1.173^{* * *}$ & 4.33 \\
$\mathrm{~N}$ & 2319 & \\
\hline
\end{tabular}

\section{Conclusions}

In China, VC firms' participation does not bring the productivity efficiency improvement in the manufactring industry. Due to the deficiencies in the legal system, cumbersome administrative approving process, and lack of transparency in the government supervision and governance structures, the entrepreneurship is still facing harsh challenges. The threats from weak intellectual protection, heavy tax burden, critical financial constraints, and unfair market competition, restrict the corporate independent innovation activities, which in turns influence the orientation and motivation of VC investments. In the lack of effective governmental regulation on the stock market, the speculation opportunity in short term investments has motivated the VC firms to involve in too much of the pre-IPOs. The premature IPO process will cause the issue firm have to take extremely high issuing costs reflected in the high leve of underpricing rate and underwriting premium, with neagtive influence on the future productivity efficiency of investees in the manufacturing sectors. All these factors finally lead to the negative correlation between VC financing and firms' TFP growth.

\section{References}

[1] Alperovych Y, Hübner G, Lobet F. How does governmental versus private venture capital backing affect a firm's efficiency? Evidence from Belgium[J]. Journal of Business Venturing, 2015,30(4):508-525.

[2] Van Den Berghe L A, Levrau A. The role of the venture capitalist as monitor of the company: a corporate governance perspective[J]. Corporate Governance: an international review, 2002,10(3):124-135.

[3] Amit R, Glosten L, Muller E. Entrepreneurial Ability, Venture Investments, And Risk Sharing[J]. Management Science, 1990,36(10):1232-1245.

[4] Rosenbaum P R, Rubin D B. The Central Role Of The Propensity Score In Observational Studies For Causal Effects[J]. Biometrika, 1983,70(1):41-55.

[5] Levinsohn J, Petrin A. Estimating production functions using inputs to control for unobservables[J]. REVIEW OF ECONOMIC STUDIES, 2003,70(2):317-341. 